adequately covered. We were, however, slightly disappointed to find no separate articles on quantum theory, on the special or general theories of relativity, or on tensor analysis. One wonders why such topics as these are not separately expounded when the scintillation counter (p.288), photoneutrino processes (p.96) and metric (p.64) each feature individually? Future volumes will no doubt supply the missing information, but for the present our thirst for understanding is not slaked.

The second question is also difficult to answer on the basis of the present volume. In general, the articles are well written. Some, indeed, are admirable, both in exposition and content. Others are less good, either failing to link the subject in hand with cognate subjects, and with the general principles involved; or attempting to cover basic theory, the history of the subject and its interrelations, all in one and the same exposé. Moreover, not all articles start from the same intellectual baseline. In one, for instance, $\pi$ and $G$ are glossed, but in another, a partial differential equation is given, without preliminaries or explanation. This case suggests that this volume is intended primarily for scholars and research workers. But if so, why do most of the articles lack bibliographies? And why are such references as are given always to books rather than to research papers?

But these are early days. We must not focus disproportionately on comparatively minor shortcomings. Subsequent volumes will surely make further improvements even on the high standard that this first volume has set. This work is of a very high standard, quite dazzling in production. Contributors and editors alike should rightly feel proud of all that they have achieved within three years. We look forward eagerly to the remainder of what promises to be a magnificent compilation.

Michael Salt and Joseph Needham are at the East Asian History of Science Library, Cambridge, UK. The most recent of Dr Needham's volumes in the series Science and Civilisation in China was published late last year.

\title{
Prehistoric Sahara of green and plenty
}

\section{Martin Williams}

\author{
Prehistory of the Eastern Sahara. By \\ F. Wendorf and R. Schild. Pp.414. ISBN \\ 0-12-743960-9. (Academic: 1980.) \$65, \\ $£ 24.20$.
}

DEFUNCT lakes and rivers, plant and animal fossils, Neolithic villages and rock paintings testify to when the Sahara was, in certain parts at least, a green and pleasant land. Nowhere is the contrast between present wasteland and prehistoric plenty more stark than in the Western Desert of Egypt. For six seasons, from 1972 to 1977 , a multidisciplinary team from Egypt, Poland and the United States laboured to reconstruct the life-style, economy and habitat of the Palaeolithic and Neolithic peoples who once inhabited the now-arid wastes between Libya and the Nile.

The book opens with a short, clear account of field and analytical methods. Four profusely illustrated chapters detail the archaeological finds and stratigraphy in each of the localities studied, after which the geographically and chronologically discrete strands are woven into two rich tapestries depicting the former environments and human exploitation of the Western Desert. A lucid, thoughtprovoking discussion of the origin of food production in northern Africa concludes the main section of the book. Ten specialist appendices follow, including evaluations of Quaternary deposits (marred by the unreadable Figure A1.1), radiocarbon dating problems, artefact and pottery analyses, the fossil record, and a scanning electron microscope study of cereal grains.
What conclusions emerge from these new data? The most interesting, best documented evidence relates to the Terminal Palaeolithic and Neolithic sites near Gebel Nabta, $100 \mathrm{~km}$ west of Abu Simbel. At Nabta playa three Holocene lake phases date to $\geq 9000, \geq 8600$ and $7000-5800 \mathrm{BP}$. Terminal Palaeolithic sites persist until the end of the first moist phase; Neolithic sites appear at the close of the ensuing dry phase. Early cattle, sheep and goat remains date respectively to 9300,8100 and 7000 BP. Attempts by the early desert dwellers to adapt to an increasingly harsh Holocene climate culminated in domestication of animals and plants over a thousand years before food production became widespread in the adjacent Nile valley.

The final exodus of Neolithic herders from the dying grasslands and shrinking lakes of the Saharan interior must have had repercussions beyond the confines of the desert. In this context, the recent migrations of starving herds and emaciated nomads during the latest sahel drought reflect the tragic but inexorable late Holocene desiccation of our greatest desert.

A fine testimonial to the dedication of the archaeologists and to the organizational skills of the two authors, this clearly written, well-produced volume deserves to be widely read by prehistorians and students of the Quaternary.

Martin Williams is Associate Professor in Earth Sciences and Director of the Quaternary Research Unit at Macquarie University, Australia.

\section{Blossoming Balkans}

\section{P.J. Grubb}

Flowers of Greece and the Balkans: $A$ Field Guide. By Oleg Polunin. Pp. $592+$ plates. ISBN 0-19-217626-9. (Oxford University Press: 1980.) £40, \$125.

THE latest in Oleg Polunin's series of illustrated guides to European plants is a most attractive introduction to the Balkan flora, which is the richest in Europe, amounting to more than 5000 species. Over 500 of these are illustrated in colour photographs and some 350 others in blackand-white drawings. The plan of the book is essentially the same as that adopted in the earlier Flowers of South-west Europe (OUP, 1973), produced jointly with B.E. Smythies. There is a general account of the climate, geology, flora and vegetation, an introduction to each of the "plant hunting regions", and then brief diagnoses of about 2000 species (320 pp.), followed by indexes of names and places, and an exhaustive bibliography. A new departure is the index of popular names used in Yugoslavia, Bulgaria and Greece. There are 22 absolutely superb colour plates of representative landscapes, but my copy lacks numbers 1 to $4-$ an unreasonable fault in a book costing $£ 40$ !

The author conveys his "feel" for the country and his enthusiasm for the plants very well. His accounts of particular regions have been vetted by local botanists, and those of the several areas I have visited myself ring true. The drawings are excellent, and the photographs constitute the usual mixture, some being of little value for critical identification but others are perfect. Whether the accounts of genera that are nowhere illustrated will be of any use to those who have not seen the plants concerned elsewhere, I doubt.

The weakest part of the book is the ecological account, particularly the section on forest and scrub communities, and it would have been better to have followed more closely the scheme of Horvat, Glavac and Ellenberg, whose map of vegetationtypes has been used as the basis for the simplified map lining the covers. More precise thumb-nail sketches of the ecology of each species described would also have been possible. The worst fault is the emphasis on 1920s' ideas of "migration routes" of plants, and the failure even to mention the appreciation built up in the 1960 s and 1970 s of the dramatic changes that occurred in Mediterranean communities during the Ice Ages, when steppe seems to have replaced much of the forest.

Despite its minor blemishes, this book will be an invaluable guide in the Balkans for those who already have a good knowledge of northern and central European plants.

P.J. Grubb is a University Lecturer in Botany at the University of Cambridge. 